\section{UK health minister under pressure to ban smoking in public}

\author{
England's chief medical officer is fighting hard \\ for a ban on smoking in public places.
}

Anyone who may have had lingering doubts about the chief medical officer's views on smoking had these swept aside by his comments at the launch of his annual report recently (7 August, p 308).

For the second year running Liam Donaldson pressed for the government to ban smoking in public places. Professor Donaldson urged the UK government to follow the lead of Ireland, New Zealand, Norway, and the US states of New York and California, where smoking in places of work and enclosed public places is banned (see news article "Infringements of Irish smoking ban are few").

While on holiday in San Francisco Professor Donaldson asked a bar worker about the infringement of liberty of a smoking ban. Her reply, he said, was powerful. "Your freedom ends where my nose starts," she told him.

Arguments that bars and restaurants would lose money if a smoking ban were imposed were ill founded, Professor Donaldson said. He had commissioned an economic analysis from the Department of Health to establish the savings from a smoking ban. It estimated that reduced absenteeism, reduced healthcare costs, and other benefits would bring savings of between £2.3bn ( $\$ 4.2 \mathrm{bn}$; €3.5bn) and $£ 2.7 \mathrm{bn}$ a year.

However, Mark Hastings, a spokesman for the British Beer and Bar Association, said: "In Ireland trade is $16 \%$ down-those figures come from sales receipts last week-and employment [in the industry] is down $14 \%$. If we were to translate that across the Irish Sea then you would see more than 75000 job losses and a loss of £3.5bn to the UK economy per annum."

Although Professor Donaldson believes a ban is the way forward, the health secretary, John Reid, is reported to oppose a ban and recently mooted the idea of restaurants and bars voluntarily introducing smoke free premises, rather than devolving the decision to local councils This would avoid the need for legislation and possible accusations of running a "nanny state."

Mr Reid's recent comments, including his view that smoking was the only pleasure of some people in deprived areas, show that his uncertainty may be personal as well as political. Mr Reid gave up smoking in January 2003

The Freedom Organisation for the Right to Enjoy Smoking Tobacco (FOREST) says that voluntary codes of practice are the "best way forward."

But according to Action on Smoking and Health (ASH) public opinion surveys have shown widespread support for restricting smoking in public places. A government survey published by the Office for National Statistics in 2003 found that $86 \%$ of respondents (including 70\% of smokers) agreed that smoking should be restricted at work, with a similar proportion wanting a restriction in restaurants.

Dr Jenny Mindell, deputy director of public health at the London Health Observatory, a body that monitors health trends in London, said: "Tobacco smoke pollution is the only known class A carcinogen that we are not protected from. If people were being exposed to asbestos or radon, it would not be 'nanny state,' it would be the government not carrying out its responsibility to protect citizens from dangers."

Dr Mindell was an author of a 2004 briefing paper for the Faculty of Public Health of the Royal Colleges of Physicians, Tobacco Smoke Pollution \& Health (available at www.fph.org.uk). It reported that 17000 children under five are admitted to hospital each year as a result of exposure to tobacco smoke, at a cost of $£ 400 \mathrm{~m}$ to the NHS.

And recent findings by Professor Konrad Jamrozik presented at the Royal College of Physicians' annual conference this year estimated that each year 4400 people in the United Kingdom die from stroke, lung can- cer, or heart disease caused by passive smoking, 730 of whom are exposed to smoke in the workplace. A recent paper in the $B M J(2003 ; 326: 1057-60)$ reinforced the findings of earlier studies linking passive smoking to coronary heart disease.

The Department of Health's own consultation paper on public health, Choosing Health? A Consultation on Action to Improve People's Health (accessible at www.dh.gov.uk), which will lead to a white paper on public health for England, acknowledges that "smoke-free places are the ideal way of protecting people from the dangers of second-hand smoke."

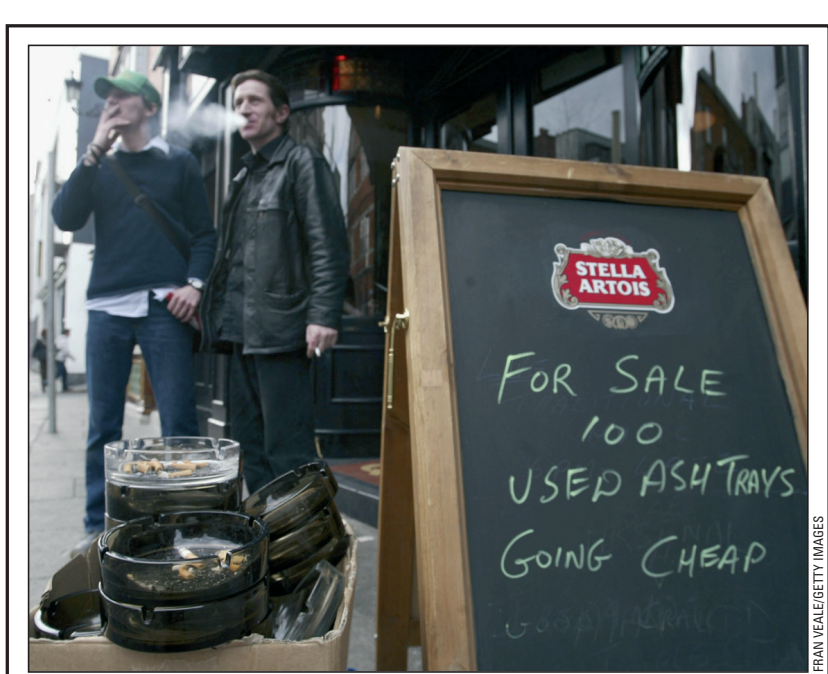

\section{Infringements of Irish smoking ban are few}

Public acceptance of the smoking ban in Ireland has been strong, although a handful of infringements have occurred.

The first pub to defy the workplace smoking ban in Ireland was Fibber Magee's, located in the main square of Galway city, one of the country's top tourist destinations. Its owners decided to allow customers to smoke on a quiet Monday night in June.

According to co-owner Ciaran Levanzin only four customers were in the pub at the time. "The next thing text messages were flying, and the place started to fill up," he said.

With the implementation of the national smoking ban on 28 March this year, the pub's decision was controversial and illegal. Within 48 hours, and facing High Court action, the owners backed down.

Two weeks later the owner of a small pub on an island off the Galway coast became the first publican to be convicted for a breach of the Public Health Tobacco Act 2004. Padraig Folan was fined $€ 1200$ ( $£ 800 ; \$ 1500)$, less than the maximum penalty of $€ 3000$, when three customers were found sitting smoking in his bar at Lettermore, County Galway.

But these isolated incidents are very much the exception. Romance is blossoming among young people congregating for a quick smoke outside Ireland's pubs. "Smirting" is the new word for the combination of smoking and flirting.

Muiris Houston Galway 